\title{
PENGARUH MANAJEMEN PERUBAHAN DAN MANAJEMEN KONFLIK TERHADAP KINERJA KARYAWAN PADA CV. ENIGMA
}

\author{
${ }^{1 *}$ Anggada Bayu Seta, 2 Sri Mulyani \\ Universitas Pamulang, Tangerang Selatan, Banten, Indonesia \\ *dosen02245@unpam.ac.id
}

\begin{abstract}
Abstrak
Penelitian ini bertujuan untuk mengetahui pengaruh manajemen perubahan dan manajemen konflik terhadap kinerja karyawan pada CV. Enigma. Metode penelitian yang digunakan adalah deskriptif dengan pendekatan kuantitatif. Hasil penelitian menunjukan Persamaan regresi berganda yang terbentuk yaitu $\quad Y=16,432+0,265 X 1+0,299 X 2$ Persamaan tersebut memberikan informasi bahwa nilai kinerja yang terbentuk adalah 16,432 dan setiap terjadi peningkatan satu satuan variabel manajemen perubahan mempengaruhi variabel kinerja sebesar 0,265. Selanjutnya, setiap terjadi peningkatan satu satuan variable manajemen konflik akan dapat mengakibatkan peningkatan nilai kinerja sebesar 0,299. Hasil pengujian hipotesis secara simultan (uji F), diperoleh nilai F hitung sebesar 24,616 lebih besar dari nilai $\mathrm{F}$ tabel yaitu 2,69, dengan demikian $\mathrm{H}_{0}$ ditolak dan $\mathrm{H}_{\mathrm{a}}$ diterima. Sehingga dapat disimpulkan bahwa variable manajemen perubahan, dan manajemen konflik secara simultan memiliki pengaruh yang signifikan terhadap kinerja pegawai pada CV. Enigma.
\end{abstract}

Kata Kunci: Manajemen Perubahan, Manajemen Konflik, Kinerja

\section{Abstract}

This study aims to determine the effect of change management and conflict management on employee performance at CV. Enigma. The research method used is descriptive with a quantitative approach. The results show that the multiple regression equation formed is $Y=16,432+0,265 \mathrm{X} 1+0,299 \mathrm{X} 2$. The equation provides information that the performance value formed is 16,432 and every time there is an increase in one unit of change management variable affects the performance variable by 0.265 . Furthermore, every time there is an increase in one unit of conflict management variable, it will result in an increase in the performance value of 0.299 . The results of simultaneous hypothesis testing ( $F$ test), obtained the calculated $F$ value of 24.616 which is greater than the $F$ table value of 2.69, thus $\mathrm{HO}$ is rejected and $\mathrm{Ha}$ is accepted. So it can be concluded that the variables of change management, and conflict management simultaneously have a significant influence on employee performance at CV. Enigma.

Keywords: Change Management, Conflict Management, Performance

\section{PENDAHULUAN}

Kualitas sumber daya manusia yang dimiliki oleh sebuah bangsa memiliki peran dan nilai strategis dalam mencapai kemajuan yang diinginkan. Seiring dengan makin modernnya perkembangan ilmu pengetahuan dan teknologi, disertai dengan diberlakukannya sistem kerja sama perdagangan bebas antar negara yang berada di kawasan asia tenggara, kini semua negara yang berada diwilayah asia tenggara saling belomba untuk meningkatkan kemampuan dan kualitas sumber daya manusia yang dimilikinya untuk dapat berkompetisi dengan negara lain.

Untuk dapat memenangkan kompetesi, setiap perusahaan diharuskan untuk mampu bertahan dan menyesuaikan diri dengan berbagai macam perubahan yang terjadi. Perubahan merupakan sebuah siklus yang pasti dan mutlak akan dialami oleh seluruh perusahaan baik yang berskala kecil, berskala menengah dan perusahaan dengan skala besar.

Perubahan yang terjadi pada tiaptiap perusahaan merupakan dampak dari adanya perkembangan teknologi yang semakin pesat tiap waktunya, perubahan 
tersebut akan dapat mempengaruhi performansi kerja perusahaan. Berdasaarkan hasil observasi penulis di lapangan, diketahui beberapa informasi terkait dampak dari adanya perubahan yang dirasakan oleh karyawan adalah, kurang pahamnya karyawan akan visi dan misi perusahaan yang menjadi sasaran perusahan dikarenakan karyawan kurang dilibatkan dalam penentuan strategi perusahaan, hal lain yang juga peneliti jumpai adalah masih terbatasnya teknologi dalam mendukung aktivitas pekerjaan karyawan.

Untuk dapat menangani perubahan yang terjadi tanpa mengganggu efektifitas kerja perusahaan diperlukan sebuah cara dan formulasi yang tepat, cara yang dimaksud tersebut dalah dengan menggunakan pendekatan manajemen perubahan.

Hal lain yang mungkin timbul dari adanya sebuah perubahan didalam tubuh perusahaan adalah konflik kerja yang terjadi diantara sesama karyawan didalam perusahan.

Permasalahan mengenai konflik kerja yang ada didalam CV. Enigma adalah, bahwa perusahaan masih belum dapat mengelola konflik dengan baik dan mengarahkan konflik yang bersifat destruktif menjadi konflik yang bersifat konstruktif dengan cara mengelola konflik yang ada menggunakan stimulasi manajemen konflik, hal ini ditunjukan dengan masih dijumpainya ketegangan yang terjadi diantara karyawan yang disebabkan oleh beberapa faktor dasar diantaranya yaitu, keterbatasan fasilitas kerja, adanya tujuan yang berbeda diantara para karyawan dalam memandang pekerjaan yang diberikan pimpinan, biasnya batasan wewenang dan tanggung jawab yang dimiliki oleh seorang karyawan yaitu dimana ada pihak yang memasuki batasan pihak lain baik secara sengaja maupun tidak, yang berujung pada timbulnya ketegangan yang diantara pihak-pihak yang terlibat konflik sehingga dapat mendorong timbulnya rasa dan keinginan karyawan untuk mengundurkan diri.

Berikut merupakan tabel data terkait konflik kerja yang diperoleh dari divisi HRD CV. ENIGMA :

Tabel 1. Tingkat Turn Over Karyawan

\begin{tabular}{|c|c|c|c|c|}
\hline No & Bulan & $\begin{array}{c}\text { Karyawan } \\
\text { Masuk }\end{array}$ & $\begin{array}{c}\text { Karyawan } \\
\text { Keluar }\end{array}$ & Jumlah \\
\hline 1 & Januari & 3 orang & 7 orang & $\mathbf{2 8 3}$ \\
\hline 2 & Februari & 2 orang & 4 orang & 281 \\
\hline 3 & Maret & 10 orang & 1 orang & 291 \\
\hline \multicolumn{4}{c}{ Sumber : Data Primer dari Divisi } \\
HRD CV. Enigma
\end{tabular}

Berdasarkan tabel 1. diatas, dapat diketahui bahwa tingkat turn over karyawan pada CV. Enigma bisa dikatakan cukup tinggi, dimana data tersebut dapat dilihat dari jumlah karyawan masuk pada bulan januari sebanyak 3 orang dan karyawan keluar sebanyak 7 orang, selanjutnya pada bulan februari tercatat karyawan masuk sebanyak 2 orang karyawan sedangkan karyawan keluar sebanyak 4 orang, sementara pada periode bulan maret karyawan masuk sebanyak 10 orang dan karyawan keluar sebanyak 1 orang karyawan.

Berdasarkan penjelasan tersebut diatas, maka dapat disimpulkan bahwa tingkat keluar masuk karyawan pada CV. Enigma cukup tinggi, hal ini dapat mengganggu efektifitas dari kinerja perusahaan dimana dengan tingginya keluar masuk karyawan, beban perusahaan akan bertambah karena adanya biaya-biaya lain yang harus dikularkan perusahaan seperti, biaya perekrutan, biaya pendidikan dan pelatihan kerja. Untuk itu perusahaan harus lebih serius dalam memandang dan menangani konflik yang ada dan terjadi didalam perusahaan sehingga tingkat keluar masuknya karyawan dapat ditekan seefektif dan sefesien mungkin.

Fakta mengenai kinerja yang ada didalam CV. ENIGMA adalah bahwa masih terdapat karyawan yang belum mencapai performa kinerja yang optimal, hal ini ditunjukan dari kesadaran karyawan dalam berdisiplin kerja seperti faktor ketepatan waktu dalam 
penyelesaian tugas dan kehadiran baik saat masuk kerja atau istirahat kerja, masih terdapatnya insiden dalam kerja yang menyebabkan kerugian bagi perusahaan akibat kurangnya pelatihan yang diterima oleh karyawan.

Berikut merupakan tabel data terkait kinerja karyawan yang diperoleh dari divisi HRD CV. ENIGMA :

Tabel 2. Tingkat Prensensi Kerja Karyawan

\begin{tabular}{|l|c|c|c|}
\multicolumn{2}{|c|}{ Office } \\
\cline { 3 - 4 } No & \multirow{2}{*}{ Bulan } & Sakit & Ijin Kerja \\
\hline 1 & Januari & 23,08 & 23,08 \\
\hline 2 & Februari & 11,54 & 15,27 \\
\hline 3 & Maret & 15,68 & 10,34 \\
\hline
\end{tabular}

Sumber : Data Primer dari Divisi HRD CV. Enigma

Berdasarkan tabel diatas, dapat diketahui bahwa tingkat ketidakhadiran karyawan diperiode bulan januari adalah sebesar 23,08\% dikarenakan sakit dan ijin kerja, selanjutnya pada periode bulan februari tingkat ketidakhadiran karyawan karena sakit adalah sebesar 11,54\% karena sakit dan 15,27 \% karena ijin kerja, dan pada bulan maret tingkat ketidakhadiran karyawan adalah sebesar 15,68\% karena sakit dan 10,34\% karena ijin kerja.

Berdasarkan penjelasan tersebut diatas maka dapat disimpulkan bahwa tingkat ketidakhadiran karyawan masih terbilang cukup tinggi, hal ini ditunjukan dari adanya jumlah absensi kerja yang terjadi selama periode bulan januari hingga maret.

Oleh karena itu, dengan mengacu kepada latarbelakang dan bukti empiris yang terjadi pada CV. Enigma, maka penulis tertarik dan berkeyakinan akan melakukan penelitian dengan judul "Pengaruh Manajemen Perubahan dan Manajemen Konflik Terhadap Kinerja Karyawan Pada CV. Enigma".

\section{TINJAUAN PUSTAKA}

1. Manajemen Perubahan

Saefullah (2010:30), "Manajemen perubahan merupakan proses secara sistematis dalam menerapkan pengetahuan, saran dan sumber daya yang diperlukan untuk mempengaruhi perubahan"

2. Manajemen Konflik

Menurut J. Winardi (2009:168), "menyebutkan bahwa manajemen konflik mengandung arti bahwa konflik dapat memainkan peranan dalam rangka upaya pencapaian sasaransasaran secara efesien dan efektif."

3. Kinerja

Menurut Sedarmayanti (2013:260), “kinerja adalah hasil kerja seorang pekerja, sebuah proses manajemen atau suatu organisasi secara keseluruhan, dimana hasil kerja tersebut harus dapat ditunjukan buktinya secara kongkrit dan dapat diukur (dibandingkan dengan standar yang telah ditentukan)".

\section{METODE}

Populasi dalam penelitian ini berjumlah 75 responden yang merupakan karyawan CV. Enigma. Sampel dalam penelitian ini berjumlah 75 responden. Jenis penelitian yang dipakai adalah kuantitatif, dimana tujuannya adalah untuk mengetahui pengaruh antara variabel bebas terhadap variabel terikat baik parsial maupun simultan Dalam menganalisis data digunakan uji instrumen, uji asumsi klasik, regresi, koefisien korelasi, koefisien determinasi dan uji hipotesis.

\section{PEMBAHASAN HASIL PENELITIAN}

\section{Pengaruh Manajemen Perubahan}

\section{Terhadap Kinerja}

Persamaan regresi sederhana yang terbentuk yaitu $Y=18,108+0,529$ $X 1$ Persamaan tersebut memberikan informasi bahwa nilai kinerja yang terbentuk adalah 18,108 dan setiap terjadi peningkatan satu satuan variable manajemen perubahan akan dapat mengakibatkan peningkatan nilai kinerja sebesar 0,529. Selanjutnya hasil pengujian hipotesis secara parsial (uji $t$ ), diperoleh nilai $t$ hitung sebesar $\mathbf{6 , 2 8 7}$ lebih besar dari nilai $t$ tabel yaitu 1,658, dengan demikian $\mathrm{H}_{0}$ ditolak dan $\mathrm{H}_{a}$ diterima. Sehingga dapat disimpulkan 
bahwa variabel manajemen perubahan memiliki pengaruh yang signifikan terhadap kinerja pegawai pada CV. Enigma.

2. Pengaruh Manajemen Konflik Terhadap Kinerja

Persamaan regresi sederhana yang terbentuk yaitu $Y=19,231+0,483$ $X 2$. Persamaan tersebut memberikan informasi bahwa nilai kinerja yang terbentuk adalah 19,231 dan setiap terjadi peningkatan satu satuan variabel manajemen konflik akan dapat mengakibatkan peningkatan nilai kinerja sebesar $+\mathbf{0}, \mathbf{4 8 3}$. Selanjutnya hasil pengujian hipotesis secara parsial (uji $t$ ), diperoleh nilai $t$ hitung sebesar 6,579 lebih besar dari nilai $t$ tabel yaitu 1,658, dengan demikian $\mathrm{H}_{0}$ ditolak dan $\mathrm{H}_{\mathrm{a}}$ diterima. Sehingga dapat disimpulkan bahwa variabel manajemen konflik memiliki pengaruh secara signifikan terhadap kinerja pegawai pada $\mathrm{CV}$. Enigma.

3. Pengaruh Manajemen Perubahan dan Manajemen Konflik Terhadap Kinerja Persamaan regresi berganda yang terbentuk yaitu $\quad Y=\mathbf{1 6 , 4 3 2 + 0 , 2 6 5 X 1}$ + 0,299 X2 Persamaan tersebut memberikan informasi bahwa nilai kinerja yang terbentuk adalah 16,432 dan setiap terjadi peningkatan satu satuan variabel manajemen perubahan mempengaruhi variabel kinerja sebesar 0,265. Selanjutnya, setiap terjadi peningkatan satu satuan variable manajemen konflik akan dapat mengakibatkan peningkatan nilai kinerja sebesar 0,299. Hasil pengujian hipotesis secara simultan (uji F), diperoleh nilai $\mathrm{F}$ hitung sebesar 24,616 lebih besar dari nilai $\mathrm{F}$ tabel yaitu 2,69, dengan demikian $\mathrm{H}_{0}$ ditolak dan $\mathrm{H}_{\mathrm{a}}$ diterima. Sehingga dapat disimpulkan bahwa variable manajemen perubahan, dan manajemen konflik secara simultan memiliki pengaruh yang signifikan terhadap kinerja pegawai pada $\mathrm{CV}$. Enigma.

\section{PENUTUP}

Kesimpulan

1. Manajemen perubahan berpengaruh signifikan terhadap kinerja, dibuktikan dengan nilai thitung sebesar 6,287 lebih besar dari $t$ tabel senilai 1,658.

2. Manajemen konflik berpengaruh signifikan terhadap kinerja, dibuktikan dengan nilai thitung sebesar 6,579 lebih besar dari t tabel senilai 1,658.

3. Manajemen perubahan dan manajemen konflik berpengaruh signifikan terhadap kinerja, dibuktikan dengan hasil F hitung sebesar 24,616 lebih besar dari F tabel yaitu 2,69.

\section{Saran}

1. disarankan agar perusahaan lebih memperhatikan perubahan yang terjadi dalam tubuh organisasi agar organisasi dapat bertahan dan dapat mengikuti perubahan yang terjadi.

2. disaranakan agar perusahaan lebih memperhatikan konflik yang terjadi di dalam tubuh perusahaan agar konflik yang tercipta tidak mengganggu kelancaran organisasi

3. disarankan bagi organisasi untuk memperhatikan kinerja yang berhasil di peroleh atau dihasilkan peusahaan agar kelancaran kegiatan operasional perusahaan perusahaan dapat tercipta dengan sebagai mana mestinya

\section{DAFTAR PUSTAKA}

AA. Anwar Prabu Mangkunegara. (2017). Manajemen Sumber Daya Manusia Perusahaan, Remaja Rosdakarya, Bandung.

Affandi, A., et al.. (2020). Optimization of MSMEs Empowerment in Facing Competition in the Global Market during the COVID-19 Pandemic Time. Systematic Reviews in Pharmacy, 11(11), 1506-1515.

Arikunto, S. (2013). Prosedur Penelitian: Suatu Pendekatan Praktik. Jakarta : Rineka Cipta.

Badri Munir Sukoco. (2019). Manajemen Administrasi Perkantoran Modern. Surabaya: Erlangga. 
Bangun, Wilson. (2018). Manajemen Sumber Daya Manusia. Jakarta: Erlangga

dan Pengembangan dalam Konteks Organisasi Publik dan Bisnis, PT. Gramedia Widiasarana, Jakarta.

Dessler, Gary. (2015). Manajemen Sumber Daya Manusia. Jakarta: Salemba Empat.

Edy. (2015). Manajemen Sumber Daya Manusia(Cetakan ke tujuh). Jakarta: Kencana Prenada Media Group

Gaol, CHR. Jimmy L. (2015). A to Z Human Capital (Manajemen Sumber Daya Manusia) Konsep, Teori,

Gaouzali, Saydam. (2000). Manajemen Sumber Daya Manusia (Suatu Pendekatan Mikro). Jakarta: Djambatan. Hasibuan,

Gusti, P. N. F., et al.. (2021). Pengaruh Human Relation Dan Motivasi Kerja Terhadap Kinerja Karyawan Pada PT. Bank Rakyat Indonesia (Persero) TBK Cabang Sorong. Jurnal Ekonomi Efektif, 3(4), 456-463.

Hasibuan, Malayu S.P. (2016). Manajemen Sumber Daya Manusia. Edisi Revisi. Jakarta: Penerbit PT Bumi Aksara.

Hasibuan, P.S. Malayu. (2015). Manajemen Sumber Daya Manusia, Penerbit: PT. Bumi Aksara, Jakarta

Malayu. (2014). Manajemen Sumber Daya Manusia. Jakarta: Bumi Aksara.

Marihot Tua Efendi. (2018). Manajemen
Sumber Daya Manusia. Jakarta: PT Grasindo. Marwansyah. (2014). Manajemen Sumber Daya Manusia, Bandung : ALFABETA.

Muslimat, A., et al.. (2020). Effect Of Organizational Commitment On The Sustainability Performance Of Indonesian Industries. PalArch's Journal of Archaeology of Egypt/Egyptology, 17(6), 8330-8347.

Nitisemito, Alex S. (2016). Manajemen Personalia (Manajemen Sumber Daya Manusia). Jakarta: Ghalia Indonesia.

Nurjaya, N., et al.. (2020). The Effect of Work Stress and Work Conflict on Employees Turnover Intention In Middle Small Micro Enterprises (MSMEs) In South Tangerang Region. International Journal of Educational Administration, Management, and Leadership, 51-62.

Sedarmayanti. (2001). Sumber Daya Manusia dan Produktivitas Kerja. Bandung : Mandar Maju.

Siagian, Sondang., P. (2018). Manajemen Sumber Daya Manusia (Edisi Pertama). Jakarta: Binapura Aksara.

Sinambela, Poltak. Lijan. (2017). Manajemen Sumber Daya Manusia. Jakarta: PT Bumi Aksara

Sugiyono. (2017). Metode Penelitian Kuantitatif, Kualitatif, dan R\&D. Bandung: Alfabeta Sutrisno. 